\title{
Increase in urinary growth hormone excretion in puberty
}

\author{
D A Price, G M Addison, E D Herbert
}

\begin{abstract}
During the pubertal years the overnight urinary excretion rate of growth hormone (hGH ${ }^{u}$ ) increases to three to four times the prepubertal rate, reaching a peak in girls at 13 years and in boys at 15 years. After puberty the mean rate of overnight $\mathrm{hGH}^{\mathrm{u}}$ is twice that before puberty.
\end{abstract}

The amount of growth hormone in the urine is very small compared with that produced by the anterior pituitary, mainly owing to the efficiency of renal tubular reabsorption and hydrolysis. ${ }^{1}$ Increased assay sensitivity has allowed the measurement of very low concentrations of human growth hormone in urine $\left(\mathrm{hGH}^{\mathrm{u}}\right),^{2}{ }^{3}$ and good correlation with serum human growth hormone has been reported. ${ }^{4}$ During a study of urinary protein excretion in normal children and adolescents we measured overnight rates of hGH ${ }^{u}$ over an age range of 4 to 18 years.

\section{Subjects and methods}

Timed overnight samples of urine were collected from 176 schoolgirls and 176 schoolboys who were in good health. There were eight to 12 boys or girls in each age group in the age range 4 to 11 years, and 15 to 22 boys or girls in each age group from 12 years upwards. Urinary volumes were measured and aliquots were stored at $-70^{\circ} \mathrm{C}$. Aliquots of urine $(5 \mathrm{ml})$ were dialysed against a phosphate buffer (membrane pore size up to 12000 daltons) for 24 hours at $4^{\circ} \mathrm{C}$ with two changes of buffer. Human growth hormone concentration was measured by a two step immunoradiometric assay: the first 24 hour incubation was with ${ }^{125}$ I labelled mouse monoclonal antihuman growth hormone and the second 24 hour incubation with sheep polyclonal antihuman growth hormone antibody coupled to solid phase, both at $4^{\circ} \mathrm{C}$. After centrifugation the pellet was washed twice with saline and gamma radiation counted for 10 minutes. Sensitivity was $1.6 \mathrm{pg} /$ tube, intraassay coefficients of variation were $2 \cdot 0-8 \cdot 1 \%$ over a range of 4.4-13.6 pg/tube, and interassay coefficients of variation were $6 \cdot 6-8 \cdot 4 \%$ over a range of $6.9-17 \cdot 3 \mathrm{pg} /$ tube. No significant change in quality control samples stored at $-70^{\circ} \mathrm{C}$ was observed over two months, the period in which all samples were analysed. Excretion rates were expressed as $\mathrm{pg} /$ minute. Statistical comparisons were made using two tailed Student's $t$ tests after logarithmic transformation.
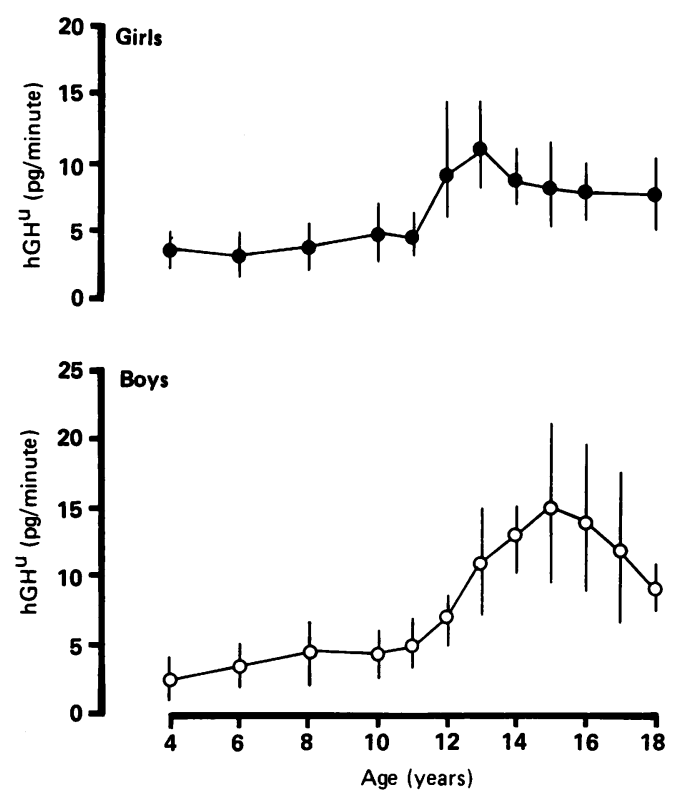

Overnight urinary excretion rates of growth hormone related to age. Results are mean and $95 \%$ confidence intervals.

\section{Results}

There was no significant change in the overnight rate of $\mathrm{hGH}^{\mathrm{u}}$ between the ages of 4 and 11 years in girls (mean $4.0 \mathrm{pg} /$ minute, range $0.8-11.4$ ) and in boys (mean $4.0 \mathrm{pg} /$ minute, range $0 \cdot 6-9 \cdot 1$ ) (figure). After 11 years of age, excretion rates rose to a peak mean concentration of $10 \cdot 5 \mathrm{pg} /$ minute (range $4 \cdot 1-28 \cdot 1$ ) at 13 years in girls and a peak mean concentration of $15 \cdot 0 \mathrm{pg} /$ minute (range $2 \cdot 2-39 \cdot 0$ ) at 15 years in boys (both peak concentrations significantly greater than the mean levels from 4 to 11 years, $\mathrm{p}<0.001)$. In girls there was a subsequent fall to a plateau between 15 and 18 years at a mean concentration of $7 \cdot 6 \mathrm{pg} /$ minute (range $2 \cdot 3-14 \cdot 2$ ) which was approximately twice that before puberty $(p<0 \cdot 001)$. A similar but later fall was seen in boys in whom the mean concentration at 18 years, $9 \cdot 3 \mathrm{pg} /$ minute (range $5 \cdot 2-17 \cdot 4$ ), was twice that in boys $4-11$ years $(p<0.001)$.

\section{Discussion}

The amount of human growth hormone measurable in urine is dependent on the secretion rate, the degree of binding to plasma proteins, the glomerular sieving coefficient for the human growth hormone molecule, and tubular reabsorption and subsequent lysosomal hydrolysis. It has been estimated that only $0.01 \%$ of
Correspondence to: Dr Addison.

Accepted 29 June 1990 
human growth hormone production is finally found in urine. ${ }^{5}$ However $\mathrm{hGH}^{\mathrm{u}}$ measurement seems to have biological meaning in that concentrations are low in hypopituitarism, high in acromegaly, ${ }^{3}$ and correlate with serum concentrations in physiological profiles. ${ }^{4}$

In the present study, the increases during pubertal years and the higher concentrations at 18 years compared with prepuberty were significant if analysed with parametric tests after log transformation or with non-parametric (MannWhitney) tests $(p<0.001)$. Although it was not possible to examine pubertal state in this study the significant rise in the pubertal years is likely to reflect increased human growth hormone production during puberty. Using data from 24 hour profiles from Mauras et al, ${ }^{6}$ there is a fourfold rise in human growth hormone production rates in boys at Tanner stages 4-5 compared with boys at stages $1-2$, which is the same relative increase in $\mathrm{hGH}^{\mathrm{u}}$ excretion in boys in this study. Furthermore the earlier peak in girls is of interest considering the earlier peak height velocity in female puberty.

Edge et al similarly showed an earlier rise in $\mathrm{hGH}^{\mathrm{u}}$ in puberty in girls and were able to relate it to breast stage 2 of pubertal development. It is of interest that $\mathrm{hGH}^{\mathrm{u}}$ was correlated to growth velocity in girls but not in boys, suggesting growth hormone dependency of the female growth spurt and perhaps testosterone dependency in the male.

Several laboratory methods are now available for the measurement of human growth hormone in urine, 8 and diagnosis of growth hormone deficiency in prepubertal children has been claimed. ${ }^{9}$ Further careful studies of normal children before and during puberty are needed to provide a sound comparison for clinical evaluation of growth disorders.

The authors wish to thank Eli Lilly and Company Limited for financial support to develop the immunoradiometric assay for urinary human growth hormone and Mrs $\mathrm{K}$ Cordwell for typing the manuscript.

1 Johnson V, Maack T. Renal extraction, filtration, absorption and catabolism of . Renal extraction, filtration, absorption and catabo

2 Hashida S, Ishikawa E, Kato Y, et al. Human growth hormone (hGH) in urine and its correlation to serum $\mathrm{hGH}$ examined by a highly sensitive sandwich enzyme immunoassay. Clin Chim Acta 1987;162:229-35.

3 Girard J, Erb T, Pampalone A, et al. Growth hormone in urine: development of an ultrasensitive assay applicable to plasma and urine. Horm Res 1987;28:71-80.

4 Okuno A, Yano K, Itch Y, et al. Urine growth hormone determinations compared with other methods in the assessment of growth hormone secretion. Acta Paediatr Scand 1987;337(suppl):74-81.

5 Baumann G, Abramson EC. Urinary growth hormone in man: evidence of multiple molecular forms. $\mathcal{F}$ Clin Endoman: evidence of multiple mol

6 Mauras N, Blizzard RM, Link $\mathrm{K}$, et al. Augmentation of growth hormone secretion during puberty: evidence for a prowth hormone secretion during puberty: evidence for a Metab 1987;64:596-601.

7 Edge JA, Hourd P, Edwards R, et al. Urinary growth hormone during puberty in normal and diabetic children. Clin Endocrinol (Oxf) 1989;30:413-20.

8 Girard J, Celniker A, Price A, et al. Urinary measurement of growth hormone secretion. Acta Paediatr Scand [Suppl] 1990;366:149-54.

9 Walker JM, Wood PJ, Williamson S, Betts PR, Evans AJ. Urinary growth hormone excretion as a screening test fo growth hormone deficiency. Arch Dis Child 1990;65:89-92. 